\title{
SUKUTUTKIJAN JäÄMISTÖ
}

MICHEL FOUCAULT: Il faut défendre la société. Gallimard 1997

\begin{abstract}
BÉATRICE HAN: L'ontologie manquée de Michel Foucault. Millon 1998
\end{abstract}

HÄNNINEN \& KARJALAINEN (toim.): Biovallan kysymyksiä. Gaudeamus 1997

CLARE O'FARRELL (toim.): Foucault Legacy. Queensland University of Technology. 1997.

\begin{abstract}
"Tekijän funktio häviää...polyseemiset tekstit tulevat jälleen kerran toimimaan toisen mallin mukaan, mutta edelleen pidäkkeiden systeemissä [...]. Me emme enää kuule kysymyksiä [...]: kuka todella puhui? Tulee olemaan muita kysymyksiä, kuten: Mitkä ovat diskurssin olemassaolon käytännöt? Missä sitä on käytetty, kuinka se voi kiertää, ja kuka voi haltuunottaa sen itselleen?"
\end{abstract}

\section{POSTUUMIN ELÄMÄN VALTA}

Erään ruumiin elämä, johon erisnimi Paul Michel Foucault kerran viittasi, lakkasi vastustamasta kuolemaa jo viisitoista vuotta sitten, mutta tuon nimen kuvaaman tekijän tekstit kiertävät edelleen aikamme keskusteluissa. Tekijänä Foucault'sta on tullut uuden diskursiivisen käytännön alkuunpanija, eikä hän näin mahdollista vain jäljittelyn ja analogioiden kautta luotua tyylisuuntaa vaan luo mahdollisuuksia myös eroille, jollekin muulle kuin perustajan omalle diskurssille, joka kuitenkin samalla kuuluu siihen mitä tämä perusti. ${ }^{1}$ Alku on heterogeeninen sitä seuraaville siirtymille, eikä näissä ole kyse luonnontieteiden tapaan perinnön tarkentamisesta vaan perityn eetoksen avaamisesta uusille sovellutuksille. Mutta tekijän käsite toimii myös keskeisenä diskurssin rajoittajana - anonyymistä kirjoittamisesta haaveillut Foucault harmitteli muuttumistaan tekijäksi, joka Hulluuden historiasta lähtien oli tunnistettu ja paikallistettu, vaikka hän pyrki jatkuvasti uusiin kysymyksiin. Foucault'lle suhde tietoon ei ollut kartesiolaisen epäpersoonallinen, vaan hän työskenteli tullakseen joksikin toiseksi. Olemme kuitenkin diskursiivisen perimämme vankeja, ja siksi toisinajattelu vaatii ajattelun koettelua, tietomme kriittistä sukuselvitystä, jonka kautta päästään eroon annetusta horisontista ja luodaan mahdollisuus uudelle näkymälle.

Tuotanto on käsite, jolla korvaamme nykyään tekijän käsitteen. Mutta miksi olemme tekijän tuotannosta kiinnostuneita? Löydämmekö tuotannon rakenteen ja sisäisten suhteiden tutkimisesta uuden diskurssien kokeilua estävän rajoitteen, vai pyrimmekö määrittämään tuotannon sen vaikutuksen ja toiminnan kautta? Foucault'n historiallisia kokemusehtoja tutkiva tuotanto voidaan ottaa rakenteellisesti haltuun järjestämällä se kolmen kokemusta määrittävän paaluun varaan: 1) kokemukseen tiedosta ja totuudesta, 2) kokemukseen vallasta ja käytännöistä sekä 3) kokemukseen itsestämme ja etiikasta. Tieto, käytäntö ja etiikka tarjovat Foucault'n luokittelevan taulukon pääsarakkeet, mutta myös kolme liikkuvaa teemaa, joiden erilainen käsittely on avannut uusien kysymysten ja diskurssien mahdollisuuksia.

\section{TIETO: TOTUUDEN HISTORIAN PARADOKSEISTA}

"Mutta filosofialla on oikeus tutkia sitä, mitä sen omassa ajattelussa voidaan muuttaa, kokeilemalla sille itselleen vierasta tietoa. Tämä [...] on filosofin elävä ruumis, ainakin jos filosofia on [...]' askeesia', itsen koettelua ajattelun alueella."

Mikä osa tiedolla on kokemuksen horisontissamme? Juuri tämä kysymys oli Foucault'lle keskeinen, Binswangerin teoksen Le rêve et l'existence käännöksen unen ja tiedon suhteita kyselevästä esipuheesta (jossa Foucault etsi unesta kuvittelukyvyn mahdollisuusehtoja) aina viimeisiin afrodisian ja totuuden suhdetta analysoiviin teoksiin saakka. Näkyvin tämä oli 60-luvun arkeologisissa töissä, joissa myös Foucault'n kriittinen kantilaisuus korostui vahvimmin. Toisin kuin fenomenologit, Foucault näki vahvan epäjatkumon Descartesin ja Kantin välillä. Foucault'lle Descartes erotti tiedon kokemuksen sfääristä, kun taas Kant liitti ne jälleen yhteen. Kant oli Foucault'lle kuten myös Heideggerille ennen kaikkea äärellisyyden ajattelija ja modernin tiedon suhteen määrittäjä. ${ }^{2}$

Tänä vuonna Ranskassa ilmestynyt Béatrice Hanin teos L'ontologie manquée de Michel Foucault lähtee liikkeelle tästä kantilaisuudesta viitaten Foucault'n 1966 lausuntoon: "Me olemme kaikki uuskantilaisia." Han väittää, että Foucault'lta löytyy selkeä filosofinen projekti, joka kulki Kantin kysymyksen historiallistamisesta (mitkä ovat diskurssin totuudellisuuden historialliset ehdot?) nietzscheläi- 
sesti virittyneeseen poliittiseen kysymykseen (mitä seurauksia on subjektille totuuden puhumisen velvoitteesta?) ja johti hänet lopulta lähelle Heideggeria kysymyksessä totuuden toiminnasta toden ja epätoden välisissä suhteissa, joiden myötä oleminen rakentuu historiallisena ja jonakin jota voidaan ja jota täytyy ajatella. Michel Haarin ja Hubert L. Dreyfusin ohjauksessa tehty teos nostaakin esiin juuri Heideggerin ja Foucault'n suhteen. ${ }^{3}$ Teoksen yleinen kuvio (Kant, Nietzsche, Heidegger) ei tuo tietenkään Foucault tutkijoille mitään uutta, Han ainoastaan esittää teeman suhteellisen koherentisti.

Hanin mukaan Foucault'lle keskeistä oli kokemuksen mahdollisuusehtojen kysymys. Transsendentaalin teema näyttää vaivaavan Foucault'ta, joka pyrki eroon tavanomaisista transsendentaaleista kohti immanentimpia käsitteellistyksiä. Vuoden 1949 diplomityön Foucault teki historiallisen transsendentaalisuuden muodostumisesta Hegelin Hengen fenomenologiassa, ja toinen väitöskirja muodostui Kantin antropologian kääntämisestä ja esipuheesta. Tuossa tekstissä näkyy Foucault'n kaksinainen suhtautuminen Kantiin. Kant kysyy ensimmäisenä esittämisen mahdollisuusehtoja rikkoen klassisen "representaation järjestyksen" itsestäänselvyyden ja avaa näin modernin ajattelun tilan sekä sen kriittisen projektin. Samalla tiedon mahdollisuuden kysymys liitetään empiiristä ja transsendentaalista koskevaan jakoon. Mutta Kantista löytyy myös tämän oman kritiikin vesittävä transsendentaalisen ja empiirisen sekoittaminen antropologisessa unessa, ihmisen hah- mossa. Hanin mukaan Foucault'n ristiriita on yritys tehdä kunniaa Kantin kysymyksenasettelulle ja päästä samalla karkuun antropologisesta hahmosta, jonka tuo ajattelu tahtomattaan synnytti. Erona Kantiin Foucault haluaa luopua sekä transsendentaalista että empiirisestä subjektista ja myös historiallistaa transsendentaalin esittämällä oman paradoksaalisen historiallisen a priorin, tiedon positiviteetin käsitteen. Tämä ei ole Husserlin Geometrian alkuperän esittämä historiallinen a priori, joka ei ole historiallinen vaan ylihistoriallinen, apodiktinen ja universaali apriorinen merkityshorisontti, joka ylittäen kaiken historiallisen faktisuuden mahdollistaa "paluun" perustavaan merkityshorisonttiin olematta kuitenkaan historian ulkopuolella. ${ }^{4}$ Niinpä universaali historiallisuus on Husserlille kaikkea faktista historiaa edeltävä ihmiskunnan horisontin olemuksellinen mahdollisuuusehto, historiallinen a priori. ${ }^{5}$ Foucault ei aseta kysymystä geometrian historiallisuudesta vaan ihmistieteiden mahdollisuusehdoista, ja hänen historiallinen $a$ priorinsa ei ole universaali vaan paremminkin pseudoapriorisesti samalla tasolla oman historiallisuutensa kanssa ja itsessään muuntuva. "Positiviteettien a priori ei ole ainoastaan ajallisen hajaannuksen järjestelmä vaan itsessään muuntuva sommitelma." Kyse ei ole siis universaalisesti välttämättömästä ja apriorisesta tiedon tai merkityksen rakenteesta vaan tietylle historialliselle muodostelmalle ominaisesta apriorisesta rakenteesta. Tiedon arkeologiassa Foucault korosti historiallisen a priorinsa eroa formaaleihin a prioreihin ja julisti, etteivät nämä kuulu samalle tasolle. ${ }^{7}$ Hanille Foucault'n arkeologiset analyysit eivät kuitenkaan koske vain ihmistieteiden alkuperän ongelmaa tai siinä esiintyviä subjektiivisuuden muotoja, vaan kyse on laajemmasta yrityksestä määritellä uudestaan historian ja filosofian yhteen nivoutuminen. Foucault haluaa välttää sekä uuskantilaisten "arvostelman idealismia" että marxilaisten redusoivaa materialismia. Myöskään fenomenologinen ratkaisu ei enää riitä Foucault'lle, joka transsendentaalisen egon sijaan etsi transsendentaalia ilman subjektia. Arkeologia on fenomenologian vihollinen myös sikäli kuin jälkimmäinen "alkuperäisen" ja "alkuperän" käsitteissään sekoittaa jälleen transsendentaalisen ja empiirisen ja jää äärellisyyden analytiikan vangiksi. Mutta mikä estää transsendentaalisen ja empiirisen paradoksissa viihtyvää paikatonta ja perusteetonta arkeologia - diskursiivisille muodostumille antamassaan "transsendentaalisessa" autonomiassa ja fenomenologiaa vastaan suuntaamassaan "empiristisemmän hahmon" iloisessa positivismissa - itse näkemästä antropologisia unia?

Foucault halusi jättää yhä vähemmän tilaa transsendentaaliselle. Etsiessään tästä pakotietä hän transsendentaalisen kritiikin arkeologisen uudelleenmäärittelyn sijaan esitti kritiikin kysymystä tarkentaakseen virkaanastujaisluennossaan (1970) genealogiaan viittavan disipliinin käsitteen. Disipliini on suhteellinen ja liikkuva periaate, joka ei ole vain kaiken totuudenmukaisesti sanotun summa vaan vaatii alaansa kuuluvalta väitteeltä tiettyjä ehtoja ja vaatimuksia. Ennen kuin jokin voi 
olla tosi tai väärä, sen on kuuluttava "totuuden" järjestykseen. Disipliini on totuuden historiallinen a priori, joka muodostuu niistä totuusehtojen sommitelmista, jotka määrittävät diskurssin hyväksyttävyyden. Hyväksyttävyyden tutkiminen johti Foucault'n myös kysymään totuuden itsensä asemaa ja muodostumista vallan vaikutusten taholta. Mikä on länsimaista tiedon kokemusta määrittävä totuudentahto, mitkä ovat sen historialliset muodot ja haarautumat? Minkälaisia ovat sen konkreettiset vaikutukset disiplinaarisissa käytännöissä ja ihmistieteiden muodostumisessa? Nyt historiallinen $a$ priori saa uuden version hallinnon (régime) käsitteestä. Kysymys on väitteiden kokoelman muodostavan lauseiden hallinnon tavasta, joka mahdollistaa väitteiden tieteellisen hyväksyttävyyden, niiden verifioinnin tai falsifioinnin. Kysymys totuuden hallinnosta tai tieteellisten lausumien politiikasta merkitsi aikaisempaa poliittisempaa otetta. Totuus ei asetu intressittömän objektiivisen intellektin alueelle vaan yhdistyy kiertäviin suhteisiin konkreettisessa vallan järjestelmässä, joka tuottaa ja ylläpitää totuutta, sekä vallan vaikutuksiin, jotka kiihdyttävät ja laajentavat sitä.

Mutta kuka ylläpitää tätä kiertoa ja minkä muodon se saa? Genealogia, joka pyrki välttämään formalismin ja materialismin, näyttää kuitenkin kallistuvan jälkimmäiseen Foucault'n asettaessa perustan paikalle hyväksyttävyyden konkreettisen historiallisen taistelun. Merkitsikö vahva kieltäytyminen transsendentaalisen matriisin käsitteellistämisestä itse asiassa villin transsendentaalin paluuta? Toi- siinsa kietoutuva tieto/valtajärjestelmä näyttää saavan itsenäisen, pseudometafyysisen olemuksen ja toteuttavan näin Foucault'n oman aikaisemman ennustuksen: "En voi välttää mahdollisuutta, että eräänä päivänä minun on kohdattava palautumaton jäännös, joka tulee olemaan, tosiasiassa, transsendentaalinen."

Totuudentahdon kysymys johtaa Foucault'n myös uuteen pyrkimykseen tutkia totuuden toimintaa minän itsesuhteessa ja subjektiksi muodostumisessa (subjectivation). Se nostaa myös esiin totuuden pelin tai toiminnan (jeux de vérité) käsitteen subjektivaatiota perustavana. Kyse ei ole vain totuuden mahdollisuusehdoista, vaan totuudesta tulee nyt itsessään keskeinen subjektin muodostumisen mahdollisuusehto. Han ottaa vahvasti esiin tämän subjektiin palaamisen ja sen aiheuttamat ongelmat. Arkeologia halusi eliminoida subjektin ankarassa kritiikissään transsendentaalia humanismia kohtaan, genealogia kritisoi intressitöntä intellektuaalista idealismia ja esitti tämän sijalle disiplinaaristen koneistojen käytännöt sekä totuuden tahdon intressin. Myös myöhäistuotannossaan Foucault kritisoi subjektin käsitettä tiedon ja historiallisuuden alkuperänä. Foucault'n uusi subjekti ei siksi ole substanssi vaan dynaaminen käsite, aina itsensä kanssa epäidenttinen muoto. Lisäksi Foucault huomauttaa, että subjektivaation prosessi, jolla saavutetaan subjektin konstituutio, on vain yksi itsetietoisuuden järjestämisen tavoista, ei universaali ja yleinen mekanismi. Han kuitenkin huomauttaa, että itsen subjektiksi muodostumisessa keskeisiä Foucault'lle ovat kuitenkin tunnistaminen ja itsereflektio ja kysyy, eikö koko tämä subjektin ongelma muistuta kaikista varauksista huolimatta kuitenkin sitä transsendentaalia subjektia, jonka arkeologia halusi hävittää? Eikö se muistuta refleksiivistä subjektia, joka on itseään koskevan tiedon kahdentuma ja samanaikaisessa tilassa ulkoisten objektien asetelmien kanssa? Kuinka ihmeessä palataan konstituoivaan subjektiin ilman konstitutiivista subjektia, ilman transsendentaalin subjektin aporioita? Kuinka yhdistää tämä subjekti disiplinaarisiin käytäntöihin? Foucault korostaa, että subjekti konstituoituu todellisissa historiallisesti analysoitavissa käytännöissä, mutta Hanille Foucault'n ristiriita on siinä, että hän määrittelee subjektivaation kuitenkin ajattelussa tapahtuvaksi refleksiiviseksi itsensä perustamiseksi. Välttääkseen idealistista subjektia Foucault korostaa ajattelun immanenttiutta ja merkityksen muodostumista itse käytännöissä ennen tietoisuuden muotoutumista. Voitaisiinko tässä nähdä pyrkimys käsittää ajattelu esiontologisesti ja säilyttää heideggerilainen intentionaalisuuden kritiikki? Han etsii analogioita varhais-Heideggerin ja myöhäis-Foucault'n välille. Foucault'n ajattelun historian tehtävänä on määritellä ne ehdot, joissa ihmisen oleminen kyseenalaistaa itsensä, tekonsa ja maailmansa, jossa tämä elää. Näin siinä voitaisiin nähdä olemisen ymmärtämisen ja sen määrittyneisyyden yhtyminen, ja Foucault kirjoittaa heideggerilaisesti olemisesta itsensä antavana ja lahjoittavana, jota voidaan ja täytyy ajatella. Subjektivaatiossa kyse ei ole konstituoivan subjektin intellektuaalisesta toiminnasta, 
vaan olemisen ymmärtäminen on immanenttia ihmisen käytännöille. Ihmisen ja subjektin käsitteitä välttävän Heideggerin tavoin Foucault ei aseta ihmiselle erillistä olemusta. Vaikka Foucault'n ja Heideggerin välille voidaan löytää yleisiä analogioita, tarkemmassa tarkastelussa nämä osoittautuvat ongelmalliseksi. Han kritisoi erityisesti toisen ohjaajansa Dreyfusin teesiä, jonka mukaan Foucault'n valta olisi samaa kuin Heideggerin oleminen eräänlaisena sosiaalisena Lichtungina. Foucault'n kysymys ei koske totuuden olemusta, ei edes tietylle epookille ominaista totuutta, vaan aina erityisiä totuuksia. Foucault'lla ei ole heideggerilaista eroa olemisen totuuden (aletheian) ja onttisten totuuksien välillä. Hanin mukaan foucault'lainen idea ei loppujen lopuksi ole edes se, kuinka ajattelu on käytännöille immanenttia esiontologista ymmärrystä, vaan Foucault näyttää korostavan ajattelun riippuvaisuutta refleksiivisestä aktiviteetista, jolla subjekti muodostaa itsensä. Hanille juuri tässä tunnistamisessa konstituoituvassa subjektissa Foucault tuo takaisin pseudotranssendentaalin subjektin, joka toimii itsessään tematisoimattomana a priorina. Pääsikö siis Foucault tiedon analyyseissään kuitenkaan koskaan eroon subjektin teemasta? Sama kysymys on asetettu koskemaan myös Foucault'n poliittisia huomioita. Pääsikö Foucault kuitenkaan koskaan eroon suvereenin käsitteestä? Koko 70-luvun Foucault'n analyysit hyökkäsivät suvereenia vastaan, jonka hän yhdisti konstituoivan subjektin teemaan. Suvereniteetin käsite oli Foucault'lle subjektin kehä itsensä suhteen, ja 70-luvun luennoissaan Foucault esitti tätä itseensä kääriytyvää kehää vastaan kehän rikkovan keskipakoisten taistelujen teeman. Jos filosofian oli herättävä antropologisesta unesta, oli poliittisen teorian lakattava näkemästä unta suvereenin esityksestä.

\section{KAMPPAILU: TODELLISTEN TAISTELUJEN VAIKUTUS}

"Meitä kannattavalla ja määrittävällä historialla on ennemmin sodan kuin kielen, ennemmin valtasuhteiden kuin kielen suhteiden muoto."

Mitkä tekstit kuuluvat tekijän tuotantoon? Foucault kielsi kaikki postuumit julkaisut, ja lähes valmis Lihan kiusaukset kiertää maailmaa vain tekijänoikeuksia rikkovana piraattiversiona. Gallimard on kuitenkin alkanut julkaista Collège de Francessa Foucault'n vuosina 1970-84 pitämiä luentoja, joista on odotettavissa yli tuhat sivua lisää tekstiä Foucault'n korpukseen. Ensimmäisenä ovat ilmestyneet vuosien 1975-76 luennot nimellä Il faut défendre la société.9 Se koostuu teosten Tarkkailla ja rangaista ja Tiedontahto väliin ajoittuvista, vähemmän hiotuista esityksistä, joissa "Yhteiskuntaa on suojeltava" -teeman alla Foucault käsittelee yhteiskunnan ympärille koostuvan biovallan eroa juridis-diskursiivisesta vallan esityksestä. Keskeisenä teemana on kuitenkin, miten sota voi toimia tapana analysoida historiaa ja sosiaalisia suhteita, ja sen varjossa esille nousevat repressio-hypoteesin kritiikki, poliittisen teorian tarve luopua suvereniteetin käsitteestä sekä kysymys biovaltaan liittyvästä modernista rasismista.
Modernia rasismia vastaan Foucault ei aseta universaalia subjektia, joka "säilyttäen ylittäisi" rotujen erot, vaan päinvastoin näkee modernin rasismin liittyvän juuri konstituoivan subjektin ongelmaan ja monistiseen näkemykseen suvereenista rodusta. Moderni rasismi on vain erityinen ja paikallistettava episodi suuressa rotujen taistelun diskurssissa, mutta episodi, joka tukahduttaa tuohon taistelun diskurssiin liittyvän poliittisen antagonismin ja kumouksellisuuden korvaten tämän biologisesti ymmärretyn yhteiskunnan hygieenisellä suojelemisella.

Konkreettisia valtasuhteita korostava 70-luvun Foucault haluaa ylistää rotujen taistelun diskurssia vastahistoriana suvereenin esitykseen kiinnittyneille historiallisille diskursseille. Benjaminilaisesti Foucault muistuttaa historiasta voittajien historiana ja historian asemasta seremonisena suvereenin ylivallan juhlintana, sen oikeuttamisena ja lisäämisenä. Foucault viittaa Dumezilin tutkimuksiin indo-eurooppalaisen tradition suvereenille antamista kaksista kasvoista, juridisista ja maagisista. ${ }^{10}$ Yhtäältä ylivalta lepää hyväntahtoisissa velvollisuuksissa, sitoumuksissa, laeissa, mutta toisaalta toiminnassa, maagisessa tehossa ja jähmettävässä kauhistuksessa tai lumouksessa. Kuitenkin kysymys on aina ylivallan asemasta järjestyksen takuuna ja perustana, samaan tapaan kuin Jupiter roomalaisena jumalana edustaa vallan runsautta ja perustaa. Tätä jupiteriaanista, suvereenin valtaa muistiinpalauttavaa, kertaavaa ja vahvistavaa "roomalaista" historiaa vastaan nousee keskiajan lopussa vastahistoria, ei-roomalainen his- 
toria, joka ei ole Rodun tai Suvereenin historia vaan rotujen taistelun historia. Vastahistorialle suvereeni ei ole loistava esitys ja perusta (kaupungin, kansan tai valtion) ykseydelle vaan orjuuttamisen ja alistamisen tapa. Tämä varjojen historia osoittaa valon ja pimeyden jakamat suvereenin kahdet kasvot ja muistuttaa loiston hylkäämästä yhteiskuntaruumiin pimeästä puolesta, jolle suvereenin laki, oikeus ja velvollisuus on kuilu, väkivalta ja anastus. Yhden historia ei ole tois(t)en historiaa, ja Hastingsin taistelun jälkeen saksilaisten historia ei ole sama kuin valloittajiksi nousseiden normannien historia.

Asettuessaan suvereenin historian ikuista jatkumoa vastaan vastahistoria käytti hyväkseen profeetallisia ja kumouksellisia teemoja. Kuten Benjaminilla, suvereenin diskurssia ja sen poikkeustilatulkintaa vastaan asettuu messianistisen lupauksen sisältävä katkoksellinen historia. Se mikä suvereenille diskurssille oli ikuinen oikeutetun vallan jatkumo oli vastahistorialle katkos, vallan anastus, alussa olleen oikeudenmukaisuuden tuhoutuminen. Olemassa olevan vallan oikeuttamisen sijaan vastahistoria viittasi asioiden väkivaltaiseen kääntymiseen ja alistettujen paluuseen ja löysi paremminkin Jerusalemista kuin Roomasta viitepisteensä. Foucault etsii modernien kumouksellisten diskurssien juuret tästä taistelun diskurssista. Jos suvereeni diskurssi yritti rauhoittaa ja vakauttaa annetun hierarkkisen järjestelmän (keskiajalla indoeurooppalaisen pyramidimaisen kolmijaon), niin vastahistoria esittää jokaista järjestystä halkovan binaarijaon, jaon alistettuihin ja alistajiin, valloitettuihin ja valloittajiin, sorrettuihin ja sortajiin. Rotujen taistelun käyttämä rodun käsite ei ole siten mikään moderni biologinen rotu, ei biologisesti stabiili olio, vaan nimi historiallispoliittisen kuilun jakamalle kahdelle ryhmälle, kahdelle elementille, joilla on eri näkemys instituutioista, oikeudesta, kielestä ja tavoista ja joiden konfliktille ei löydy kolmatta sovittavaa neutraalia termiä.

Moderni rasismi korvaa tämän kahden vieraan ryhmän antagonismin biologisesti monistisella rodun käsitteellä. Valtio ei ole enää yhden rodun ase toista vastaan vaan yhtenäisyyden ja rotupuhtauden takaaja. Valtiollinen ja biologinen monismi tukahduttaa rotujen taistelun antagonismin. Foucault'lle moderni valtiollinen rasismi oli rotujen diskurssi ympärikäännettynä. Se ei enää toiminut kumouksellisena vastahistoriana suvereenille vaan välineenä yhtenäisen yhteiskunnan suvereniteetin säilyttämisessä. Kyse ei vain ollut enää juridis-maagisista vaan lääketieteellis-normatiivisista välineistä. Siirryttiin laista normiin, oikeudesta biologiaan, rotujen moninaisuudesta yhteen rotuun. Kansallisosialismi tosin käytti hyväkseen valtiollis-teknologisesta puhtausrasismistaan huolimatta myös rotujen taistelun eskatologisia, populistisia ja teatraalisia elementtejä kun taas Neuvostoliitossa rotujen taistelusta periytyvä luokkataistelun kumouksellinen teema muutettiin nopeasti järjestetyn yhteiskunnan hiljaiseksi poliisihygieniaksi.

Foucault etsi rotujen taistelun teemasta erityistä historiallis-poliittista diskurssia, jossa historiaa analysoidaan so- dan termeillä. Toisin kuin juridis-poliittinen diskurssi, tämä ei kiinnittäisi huomiotaan suvereniteetin oikeuttamisen ympärille kerääntyviin juridisiin fiktioihin ja esityksiin vaan konkreettisiin historiallisiin alistuksen ja valloituksen muotoihin. Sodan diskurssissa puhuva subjekti ei ole universaalin totuuden puhemies, lainsäätäjä-filosofi, vaan taisteleva subjekti, jonka totuus on aina taistelun näkökulman ja strategian tuotos. Tämän subjektin puhuma totuus on ase, jonka tarkoitus on tuoda voitto taistelussa. Sodan diskurssi on vastakkainen poliittis-juridiselle teorialle, sillä toisin kuin jälkimmäiselle, sille vallan juridinen rakenne ja suvereeni yhteiskuntajärjestelmä ei ala hetkellä, jolloin aseiden hohto häviää. Laki ei merkitse sodan torjumista, se ei synny luonnosta vaan todellisista konflikteista, verilöylyistä, valloituksista ja voitoista, joilla on omat päivämääränsä ja kauhistuttavat sankarinsa. Yhteiskunnan läpi kulkee antagonistinen binaarikoodi: on aina kaksi ryhmää, kaksi ihmisten kategoriaa, kaksi armeijaa. Jokainen on jonkun toisen vihollinen eikä neutraalia subjektia ole olemassakaan. Tämä ei kuitenkaan merkitse hobbesilaista kaikkien sotaa kaikkia vastaan; Foucault esittää luennoissaan oman strategisen Hobbes -tulkintansa. Leviathan ei edusta sodan diskurssia vaan on esimerkki juuri sodan diskurssin torjuvasta suvereniteetin juridis-poliittisesta tulkinnasta. Hobbes näyttää ensinäkemältä asettavan sodan valtasuhteiden perustalle, mutta Foucault'n mukaan sen sijaan, että Hobbes olisi sodan ja valtasuhteiden teoreetikko, tämä pikemminkin halusi 
poistaa sodan historiallisena todellisuutena, aivan kuin Hobbes olisi halunnut poistaa koko sodan suvereniteetin alkuperästä. Hobbesin kuviteltu sota ei ole vahvan ja heikon välinen sota, se ei synny luonnollisista eroista vaan niiden puutteesta eli luonnollisesta tasa-arvoisuudesta. Voimien ero tekisi sodasta hyödytöntä, sillä se loppuisi vahvemman hallintaan. Hobbes taas tarvitsee suvereenin esityksen lopettamaan sotatilan, juuri koska sen tasaarvoisessa asetelmassa kukaan ei kykene lopettamaan sotaa asettamalla ylivaltaansa. Foucault huomauttaa, kuten Leo Strauss aikaisemmin, ettei Hobbesin sotatila ole mikään suora ja todellinen voimien mittelys, jonka merkkeinä olisivat veri, taistelut ja ruumiit. Hobbesin sotatila on tietty representaatioiden tila, jossa niitä pelataan toisiaan vastaan. Vaikka Hobbes puhuu sopimuksella perustettavan valtion lisäksi myös valloituksella perustettavasta valtiosta, niin valloitus ei ole hänelle todellinen suvereniteetin perusta. Edes tässä voitto ja alistaminen eivät perusta valloittajan valtaa vaan paremminkin kyky tunnistaa valloittaja poliittisena representaationa, edustajana. Tunnistaminen ja halu valita elämä ennemmin kuin kuolema on Hobbesin suvereniteetin perustassa. Foucault'lle Hobbes halusi poistaa valloituksen diskurssin poliittisesta diskurssista, ja Leviathanin näkymätön vihollinen on juuri valloittaja.

Sopimusteoria esittää kuvitellun teorian valtion perustassa olevasta yksilöiden tekemästä sopimuksesta, mutta nietzscheläiselle Foucault'lle konkreettisesti valtion perustavat valloittajat. Kuten Carl
Schmitillä, jokaisen järjestyksen alkuperässä on väkivaltainen haltuunotto. Sodan diskurssin mukaan valtion alkuperässä ei ole sopimusta vaan sota, ei filosofien kuvittelema ideaali tai fiktiivinen kaikkien sota kaikkia vastaan vaan todellinen historiallinen sota ja siinä tapahtuneet konkreettisesti vaikuttaneet taistelut. Clausewitzin lausuma "sota on politiikan jatkamista toisin keinoin" on itse asiassa tämän sodan diskurssin nurin kääntämistä, ja Foucault kääntää sen jälleen ympäri muotoon: politiikka on sodan jatkamista toisin keinoin. Vaikka Foucault esittää sodan diskurssin lähinnä vaihtoehtoisena tapana analysoida historiallista olemistamme, näyttää hän myös 70-luvulla affirmoivan tämän strategisen sodan diskurssin poliittisen toiminnan periaatteena. Foucault'n vahva antagonismin affirmaatio vaikuttaakin välillä lähes ympäri käännetyltä "saksalaisroomalaiselta" Carl Schmittiltä - eli "ranskalais-anarkisti" Georges Sorelilta. Foucault tietenkin haluaa kritisoida poliittisen teorian käyttämiä abstraktioita ja osoittaa näiden abstraktioiden materiaalisen muodostumisen ja muistuttaa sodan diskurssin kautta taistelun periaatteesta, jonka poliittinen teoria on pyrkinyt aktiivisesti unohtamaan. Mutta kuten Pasquale Pasquino on huomauttanut ${ }^{11}{ }^{11}$ Foucault'n valloituksen ja taistelun diskursseista etsimä binaarirakenne löytyy myös Hobbesia edeltäneestä politiikan teoriasta niin köyhien ja rikkaiden konfliktista Aristoteleel$\mathrm{la}^{12}$ kuin ylhäisön ja rahvaan vastakkainasettelusta Machiavellilla. ${ }^{13}$ Machiavelille juuri institutionalisoitu konflikti loi Rooman suuruuden. Tässä suhteessa poliittinen teoria on myös yrittänyt luoda mahdollisuuksia konfliktin kestämiselle. Ääriantagonistinen diskurssi ei kykene itse asiassa elämään konfliktissa vaan jää itse kiinni apokalyptisen viimeisen taistelun teemaan. Pasquino puolustaakin Hobbesia siinä mielessä, ettei tämä ainoastaan halunnut kieltää sotaa vaan myös lopettaa jatkuvan sisällissodan ja ajatuksen yhdestä lopullisesta taistelusta, joka lopettaisi kaikki taistelut.

Tietenkin myös Foucault kritisoi vankasti yleistetyn ja yhden suuren taistelun teemaa ja esitti sen sijaan moninaisten ja paikallisten vastarinnan pisteiden ja muotojen strategian. Jos 60-luvun Foucault'lla kieli törmää rajoillaan anonyymiin muminaan, joka on samalla sen raja ja ehto, niin samoin valta kohtaa rajoillaan vastustuksen, jonka hallinnointiin kaikki valta perustuu. Foucault nimeää vastustuksen rahvaaksi, ylijäämäksi, jakojäännökseksi, joka ei jousta hallinnan tekniikoille. Machiavellilla rahvaan ja ylhäisön antagonismi on juuri hallitsemishalun (ylhäisö) ja hallinnan vastustushalun (rahvas) välinen taistelu. Foucault'lle rahvas ei ole olio eikä yhtenäinen ryhmä, jonka puolestapuhujaksi intellektuelli voisi asettua jonkinlaisena ryysyläisköyhälistön edustajana tai jonka nimissä kumoukset voitaisiin oikeuttaa, vaan aspekti, laatu, keskipakoinen voima valtasuhteille. Se on elementti, joka on yhtä paljon työläisissä kuin porvareissa, vastarinnan piste meissä kaikissa eli se mikä meissä pakenee hallintaamme ja jota yritämme hallita. ${ }^{14}$ Jos hallinnollisuuden ongelma kysyy sitä miten meitä hallitaan, miten hallitsemme itseämme, on rah- 
vaus elementti, joka vastustaa hallintaa, mutta samalla vaatii hallintaa ja jonka hallinnoimiseksi hallinnan diskurssit muodostuvat.

Rahvas on suvereenin hallinnan pimeät kasvot, jotka näyttäytyvät erilaisissa muodoissa. Kansansuvereniteetille se on kansan osa, joka ei hallinnoidu ja siksi tarvitsee hallintaa. Ranskan vallankumous ei tuonut politiikan näyttämölle vain tasa-arvoisten kansalaisten järjestäytynyttä yhteistahtoa vaan näyttämöä likasi myös elementtien (kurjaliston, irtolaisten, prostituoitujen jne.) läsnäolo, jotka kuuluivat kansakuntaan siihen kuulumatta ja jolta yhteiskunnan oli suojeltava itseään. Köyhälistön käsite oli yksi tapa käsitteellistää rahvasta, ja köyhyyden hallinnoinnista muodostui keskeinen teema moderneissa hallintodiskursseissa. Köyhyyden käsitettä tutkineet, kuten Gertrudd Himmelfarb, ovat usein korostaneet käsitteessä tapahtunutta siirtymää moraalisesta taloudelliseen määritykseen. ${ }^{15}$ "Foucault'laiset" taas ovat tutkineet käsitettä osana hallinnollistumista kuten Mitchell Dean tutkimuksessaan köyhyyden asemasta liberaaleissa hallintostrategioissa. ${ }^{16}$ Dean on myös yksi kirjoittajista Sakari Hännisen ja Jouko Karjalaisen toimittamassa Biovallan kysymyksiä -kokoelmakirjassa, jonka artikkelit käsittelevät juuri köyhyyden ja sosiaalisten uhkien hallinnointia.

\section{HALLINNOINTI: RAHVAAN KESYTYS}

\section{"Me elämme hallinnollistu- misen aikaa."}

Kysymys biovallasta ja väestön asema modernin hallin- noinnin ensisijaisena kohteena johti Foucault'n pohtimaan hallinnollistumisen teemaa vastakohtana vanhalle teologis-monarkkiselle herruuden teemalle. Biovallan keskeinen periaate on kuolemanuhkaan perustuvan herruuden korvaaminen elämän tuottavalla ja joustavalla hallinnoinnilla, ja hallinnoimisen teema korostui erityisesti aikaisempaa valtion ja kuninkaan yliherruutta kritisoivissa liberaaleissa diskursseissa. Miten hallita sopivasti hallitsematta liikaa? Itsen hallinnan tutkiminen johti Foucault'n selvittämään haluavan ihmisen sukupuuta aina antiikin Kreikasta lähtien, mutta Foucault'lla säilyi myös vanha halu palata kesken jääneeseen liberaalien hallintostrategioiden tutkimiseen. Ranskassa on viime aikoina pohdittu ahkerasti keskiajan hallintoa, klassista valtiojärjen käsitettä ja moderneja yhteiskuntatieteiden ja hyvinvointivaltioiden hallinnollisia strategioita. Italiassa on innostuttu hallinnollistumisen teemasta ja Englannissa foucault'lainen näkökulma on usein yhdistynyt vahvaan sosiaalihistorian traditioon.

Italian ja Englannin keskusteluita seuranneen Hännisen toimittama kirja sisältääkin italialaisen sosiologin Procaccin lisäksi englantilaisen keskustelun veteraanien tekstejä kuten Nikolas Rosen ja Peter Millerin artikkelin. Mukana on myös tieteenhistorioitsijan ja filosofin Ian Hackingin kevyempi ja myös sekavampi teksti lasten hyväksikäytöstä. Hacking, joka on kirjoittanut muun muassa kaksi erinomaista kirjaa tilastotieteiden historiasta, ${ }^{17}$ ei ole ollut millään lailla foucault'lainen, mutta oli yksi Foucault'n teosten ensimmäinen johdat- telija anglosaksisen kiinnostuksen kohteeksi. Hacking analysoi lasten hyväksikäytön käsitteen muodostumista, muuntumista ja siihen liittyviä ongelmia korostaen sitä miten ihmisiä koskeva tieto, luokittelut ja käsitteet, muodostavat itsessään ihmisiä ja muokkaavat heidän toimintaansa, joka taas muokkaa luokituksia ja käsitteitä. Hacking onkin korostanut luonnontieteiden ja ihmistieteiden eroa. Vaikka luonnontieteet tuottavat luontoa muokkaavaa tietoa ja myös muuttavat käsitystämme "luonnosta", ankarasti ottaen ne eivät muuta itse "luonnon" käytöstä. Kivi itsessään ei muuta käytöstään ja olemustaan sen mukaan minkälaista tietoa siitä tuotetaan, mutta tiedon kohteena olevien ihmisten laita on toisin, ja suhde tiedon subjektin ja objektin välillä on aina kaksisuuntainen ja liikkuva. Hauska historiallinen kuriositeetti on artikkelin mainitsema eläinsuojeluyhdistysten rooli lapsiin kohdistuvan julmuuden esiintuomisessa. Nykyäänhän vailla täysiä oikeuksia olevat lapset ovat ottaneet esille eläimiin kohdistuvan julmuuden - moraalittomaksi haukuttu nuoriso on heittänyt eteemme ankaran moraalivaateen ja ajautunut huolensa kanssa konfliktiin omistusoikeuksiaan puolustavien huolettomien aikuisten kanssa. Biovaltaan liittyvät teemat artikkelissa ovat kuitenkin kysymykset medikalisoitumisesta ja siitä, miten lasten hyväksikäytössä julmuuden teema muuttui vanhempien sairauden teemaksi. Miten tapahtui käsitteen medikalisoituminen ja sen siirtyminen oikeusistuimien huolesta lääkäreiden huoleksi?

Kysymys seksuaalisesta hyväksikäytöstä nostaa esiin on- 
gelman lain ja seksuaalisuuden suhteesta. Foucault ehdottikin seksuaalisuuden vapauttamista lainsäädännöstä ja esimerkiksi raiskauksien tuomitsemista väkivallantekoina eikä "seksuaalirikoksina". Oikeuden psykiatrista medikalisoitumista Foucault taas käsitteli Toronton Laki ja psykiatria -symposiumissa pidetyssä esitelmässä: "Vaarallisen yksilön käsite 1800-luvun oikeuspsykiatriassa". Voitaisiin puhua rikosoikeuden dostojevskilaisesta käänteestä, jossa "rikos ja rangaistus" -diskurssissa keskeiseksi mielenkiinnon kohteeksi nousee teon sijaan tekijän olemus, Raskolnikovin psykologia. Kyse on siirtymästä aktuaalisesta teosta yksilössä asustavaan mahdolliseen vaaraan, syyllisen sovittavasta rangaistuksesta yhteiskunnan absoluuttiseen suojelemiseen. Rikoksesta siirrytään rikoksen mahdollisuuteen, rikollisen kurinalaistamiseen ja tähän sisältyvän riskitekijän kontrollointiin. Foucault'lle vaarana on, että lopulta laki puuttuu yksilöihin puhtaasti sen pohjalta minkälaisia he ovat, ennen mitään tekoja.

Sakari Hänninen käsittelee kyseisen artikkelin pohjalta oikeudenkäytön muutosta biovallassa, siirtymää kosmista järjestystä vastaan suunnatuista teoista (paraatiesimerkkeinä majesteettirikos ja isänmurha) ja tämän järjestyksen palauttavasta rituaalisesta rangaistuksesta yhteiskuntaa kohtaan kohdistuvan vaaran eliminointiin. Vaarallisen yksilöön liittyy tunnustamisen kautta toimivan tunnistamisen teema. Kysymykseen "kuka olette?" ei riitä vastaukseksi pelkkä tunnustus "olen rikoksen tekijä", sillä tuomitessaan tekijän sen mukaan minkälainen tämä on ihmisenä ja mahdollisena kurinpitokoneiston kohteena vaaditaan tästä itsestään tuotettua puhetta. Hänninen yhdistää tunnistamisen ja tämän kautta muodostuvan identiteetin kysymyksen yleisesti Foucault'n kysymykseen siitä, keitä me olemme ja miten jäsennämme identiteettiämme ulkoistamalla joitakin muita ihmisiä. Hänninen viittaa myös oikeussaleissa tuotetun puheen taustalla olevan hiljaisuuden kuuntelemiseen normalisoivan puheen peittämien mahdollisten riitojen ja kamppailujen esiin nostamisena ja huomauttaa Foucault'n kiinnostuksesta plebeiji- ja pilkkaväestöä kohtaan. Kuten edellä todettiin, Foucault'lle rahvaan käsite on juuri paikka artikuloimattomalle vastarinnalle, nimi sille hiljaisuudelle, joka on hallinnan puheen lähde ja raja.

Köyhyyden hallinnoinnin diskurssi oli yksi tapa tuottaa puhetta tuosta hiljaisuudesta ja antaa rahvaalle hallittavat kasvot. Giovanna Procacci esittää sosiologian synnyn köyhyyden hallinnoinnin yhteydessä ja käsittelee yhteiskuntatieteitä tapana hallita yhteiskunnallisia voimia ja tapahtumia. Jacques Donzelot analysoi sosiaalisen alueen syntyä hallinnon alueena kuuluisassa teoksessaan Perheiden hallinnoinnista, ja myös Procacci etsii niitä historiallisia tapahtumia ja ehtoja, jotka tekivät yhteiskunnallisen näkemyksen mahdolliseksi. Miten muotoutui prosessi, jota Comte kutsui "yhteiskunnallisen näkökulman yleispäteväksi henkiseksi voimaksi"? Proccacilla yhteiskuntatiede asettuu valtion ja talouden konfliktin välimaastoon, ja sen syntymiseksi oli oltava ongelmien joukko ja käytäntöjen kenttä, joita vaihtoehtoi- set oikeudelliset ja taloudelliset lähestymistavat eivät pystyneet käsittelemään. Yhteiskuntatieteet kehittivät alusta asti tekniikoita, jotka sijoittuivat suvereenin yksilön oikeuksien ja taloudellisten toimijoiden etujen välimaastoon. Ne pyrkivät rakentamaan tieteellisiä ratkaisuja poliittisiin ongelmiin, joiden edessä oikeus ja talous olivat voimattomia. Yksi näistä oli köyhyys, ja yhteiskuntatieteiden muotoutuminen liittyi läheisesti vaurastuvan yhteiskunnan uuteen käsitykseen köyhyyden hallinnan keinoista.

Köyhiät olivat Ranskan vallankumouksen jälkeen ongelma. Ancien regimessä heidän tilallaan olivat vailla oikeuksia olevat ja holhouksen alle tuomitut kerjäläiset. Mutta vanhoja etuoikeuksia vastaan hyökännyt vallankumous oli tehnyt kaikista luonnonoikeudellisesti tasaarvoisia. Myös köyhät olivat kansalaisia, ja kuitenkin he tekivät epätasa-arvoisuuden näkyväksi. He olivat rikkaruoho puhtaan tasa-arvoisuuden pelikentällä. Heidän täytyi kuulua oikeuden alueeseen, mutta samalla siihen kuuluvina luopua köyhyydestä. Miten eliminoida köyhyys ja liittää köyhät yhteiskuntaan? Yksi vastaus oli työ, ja Procacci tarkastelee etenkin vuoden 1848 vallankumousta ja siinä esitettyä vaatimusta työhön. Työn tuli toimia poliittisena ja oikeudellisena ratkaisuna alempien luokkien köyhyysongelmaan. Vaatimus esitettiin oikeuden nimissä, vaikkei puhtaasti oikeudellinen diskurssi voinut sitä ratkaista. Positiivista oikeutta ei voitu liittää luonnollisiin oikeuksiin, ja valtion rooli positiivisten oikeuksien turvaajana olisi taas 
tehnyt siitä taloudellisen toimijan, jota taloudellinen liberalismi vastusti. Filantropiaa ratkaisuna korostava sosiaalitalouden diskurssi syntyi halusta välttää sekä talouden tekemistä syylliseksi köyhyyteen että valtion muodostumista taloudelliseksi toimijaksi vaatimuksissa valtion takaamasta oikeudesta työhön. Filantropiasta tuli tapa erottaa köyhyysongelma työstä ja taloudesta, erottaa taloudellinen vapaus (yksilön etu) veljeydestä (yleinen etu) ja tehdä köyhyydestä yhteiskunnallinen ongelma sekä yleisen moraalisen huolen ja avustuksen kohde.

Sosiaalitalous teki kuitenkin köyhyydestä puhtaasti poliittisen kysymyksen ja uhkasi myös politisoida talouden. Sosiaalitalouden kriitikoille taloudellista tuotantoa ohjasivat vakaat lait ja köyhyys oli näiden muuttumattomien lakien seuraus, sitä ei voitu täysin poistaa. Sen sijaan moraalista köyhyyttä, kansalaisissa piilevää laiskuutta, tuhlaavaisuutta ja vastuuttomuutta voitaisiin hoitaa tuottamalla parempia välineitä yksilöiden yhteiskuntaan sopeuttamiseksi. Sosiaalisen vastuun puute synnytti sosiaalista köyhyyttä ja tätä hoitamaan voitaisiin suunnata sosiaalitekniikoita. Sosiologia tarjosi juuri juridisen oikeuden ja taloudellisen edun käsitteen antagonismin ylittäväksi kolmanneksi termiksi sosiaalisen velvollisuuden käsitteen, jonka tuli vahvistaa yhteiskunnan ytimeksi asetettua sosiaalista sidosta (lien social). Oikeudellisen tasa-arvon ja taloudellisen vapauden lisäksi hallinnoinin kohteeksi tuli vallankumouksen kolmas termi: veljeys ja solidaarisuus. Syntyi sosiaalisen vaiston loputon kasvatuskenttä, jonka piti taata maal- listuneen yhteiskunnan yhtenäisyyden side ja siirtymä oikeuksien demokratiasta velvollisuuksien demokratiaan.

Procaccin analysoidessa yhteiskuntatieteiden syntyä köyhyyden ongelman tieteellisenä ratkaisuna, Mitchell Dean tekee vuorostaan sukuselvitystä köyhyyden asemasta liberalistisen hallinnon sukupuussa. Dean korostaa, ettei liberalistista hallinnoinnin tapaa tule sekoittaa liberalismiin tai liberalistiseen valtioon, vaan se viittaa hallitsemisen (governance) tapaan, joka suhtautuu kriittisesti aikaisempaan paternalistiseen ja pappisvaltaiseen herruuteen (rule) ja yrittää asettaa tälle vallalle pidäkkeitä vetoamalla henkilökohtaiseen tai yksityiseen elämänpiiriin. Kyse on joukosta institutionaalisia ja hallinnollisia käytäntöjä, joilla pyritään koordinoimaan valtion, hyväntekeväisyyden, perheiden ja talouden eri toimintapiirejä tiettyjen käyttäytymismuotojen edistämiseksi. Paradoksaalisesti sitä luonnehtiikin kyky laajentaa määräysvaltaa asettamalla rajoja valtion toiminnalle ja jakamalla vastuuta ihmisten elannosta yksittäisten toimijoiden, valtion ja muiden instituutioiden kesken. Deanin mukaan liberalistisen hallinnointitavan muodostuessa syntyi uusi hallinnon ja tietämyksen kohde, köyhyys erotettuna köyhistä (tai paremminkin kerjäläisistä, irtolaisista jne.). Dean vertailee vanhaa valtiomerkantilistista poliisijärjestyksen köyhien hallintaa uusiin liberalistisiin köyhyyden hallinnoinnin taktiikoihin. Poliisijärjestykselle ensisijainen kysymys oli: "Mikä on kansakunnan köyhien lukumäärä ja mistä se muodostuu?" Ongelma esitettiin kansallisen merkanti- lismin diskurssille alisteisena, jossa kysymys oli väkirikkauden merkityksestä kansakunnan varallisuuden ja suuruuden takeena sekä irtolaisuuden ja kerjäläisten asemasta yleistä järjestystä häiritsevinä elementteinä. Käytännöllinen tiedon muoto lajitteli köyhät liittäen määrittelyihin toimenpidesuosituksen. Työtä tekeville (teollisuusköyhälistö) oli annettava töitä, työtä tekemättömät (joutilaat köyhät) oli pakotettava töihin ja työhön kykenemättömille oli annettava leipää ja avustuksia. Moderni köyhyyden käsitys taas liittyy siirtymään, jossa Malthusin ja Ricardon kautta perustavasta niukkuudesta ja puutteesta tuli luonnon keskeinen ominaisuus ja taloudellisen toiminnan perusta. Tämän niukkuuden ulottaminen inhimilliseen yhteisöön sai nimen köyhyys. Köyhyys (niukkuus) nousee koko taloudellisen diskurssin keskiöön, köyhyydestä tulee erityinen ihmisten olemisen tapa, joka johtuu ihmisen yleisestä olemisesta väestön, ravinnon ja pääoman biotalouden alaisena. Köyhyydestä tulee itse asiassa välttämätön tekijä ihmisen olemassaolossa. Samalla köyhyyden käsite irtoaa staattisesta köyhien luokittelujärjestelmästä ja luo yksityiskohtaisemman ja joustavamman luokittelujärjestelmän. Jos köyhyys on luonnon niukkuuden auttamaton laki ja jos bioekonominen välttämättömyys toteutuu, kun subjektin ainoa omaisuus työvoima vaihdetaan elämän perusedellytyksiin, niin sen yhteiskunnalliset kasvot, pauperismi ("köyhäläisyys") oli tämän lain rikkomista. Hallinnollinen rationalismi kohdistui juuri pauperismiin, köyhyyden sosiaaliseen ilmenemismuotoon, työn mahdol- 
listaman omavastuun vääristymään, joka ei ollut työn (joka itsessään perustuu luonnon niukkuteen, köyhyyteen) vastakohta vaan itsenäisen työläisen toteuttaman elämäntavan vastakohta. Bentham pyrki luokittelemaan tarkasti tämän historiallista dynamiikkaa uhkaavan, koko tuottavan elämän ulkopuolelle jäävän aineksen. Benthamin hallinnollinen mielikuvitus rakensi mitä kattavimpia kartoituksia köyhyyden, tuon kaikkialta aina ihmiskuntaa uhkaavan tekijän hallinnoimiseksi pystyen kuitenkin sovittamaan nämä totaaliset ohjelmansa samalla liberalistisen taloustieteen vapauden periaatteisiin. Benthamin hallinnolliset utopiat ja Malthusin abolitionismi, totaalinen hallinto ja antihallinto, biopoliittinen unelma ja bioekonominen välttämättömyys ovat Deanille liberalistisen köyhyyden hallinnon kaksi perusulottuvuuta, joiden välillä erilaiset konkreettiset hallinnan tekniikat muodostuivat. Liberalistisessa köyhyyden hallinnoinnissa poliisijärjestyksen patriarkaalisen valtiotalouden mallin tilalle tuli juridisesti spesifioitu yksityisyys, joka rakentui moraalin ja talouden kaksoisakselin ympärille. Moraali on kuitenkin alistettu talouden akselille ja työnnetty kokonaan henkilökohtaisen alueelle. Deanin mukaan tärkeä poliittinen kysymys ei niinkään koske sitä, kuinka hyvinvointirakenne saadaan vastaamaan paremmin tiettyjä eettisiä periaatteita, vaan meidän tulisi kyseenalaistaa se rationaalisuus, joka tekee jatkuvasti köyhyydestä välttämättömän osan elämänmuotoamme.

Myös Miller ja Rose haluavat muistuttaa, ettei meidän tulisi hyväksyä köyhyyttä yk- sioikoisena ja väistämättömänä tosiasiana, vaan riippumatta siitä, mitä kärsimyksen raaka todellisuus ikinä pitääkin sisällään, hallinnan kohteena köyhyys on elimellisesti sidoksissa tiedon, laskelmoinnin ja hallinnan muotoihin. Miller ja Rose käsittelevät kahta ajankohtaisempaa köyhyyden hallinnan muotoa, hyvinvointijärjestelmää ja sen kritiikkinä syntynyttä uusliberalistista hallintorationaalisuutta lähinnä englantilaisessa kontekstissa.

Hyvinvointijärjestelmän hallintateknologian uutuus perustui sen pyrkimykseen kytkeä valtiokoneiston rahalliset ja byrokraattiset voimavarat yhteiskuntaelämän liberaalisdemokraattiseen hallintaan. Hyvinvointijärjestelmä on hallintorationaalisuutta, joka järjestäytyy yhteiskunnallisen riskin ja vastuun vastavuoroisuuden käsitteiden ympärille pyrkien yhdistämään jatkuvasti ennaltaehkäisevää ja vastavuoroista ulottuvuutta. Sosiaalivakuutus ja sosiaalityö ovat Englannissa olleet sen kaksi pääasiallista teknologiaa. Sosiaalivakuutus luo sopimuksellisen suhteen kansalaisen ja julkisen vallan välille ja sosiaalityö asettaa eräänlaisen valvomissuhteen asiantuntijan ja sellaisen yksilön tai perheen välille, joka ei kykene lunastamaan "yhteiskuntasopimuksen" velvoitteita. Taustalla toimii vastuullistamisen etiikka. Valtio ottaa vastuun kansalaisen tuntemasta turvattomuudesta sairauden, saastaisuuden, tietämättömyyden ja puutteen ongelmien edessä ja palkkaa asiantuntijoita hoitamaan näitä ongelmia. Vastikkeeksi kansalainen kunnioittaa velvollisuuksia olla säästäväinen, yritteliäs ja vastuullinen. Tämä vastavuoroinen sosiaalinen vastuu yhdistyy yhteiskuntasuunnitteluun, jossa suunnitellun tuotannon, asumisen, koulutuksen ja terveydenhuollon tulisi nostaa kansalainen poliittisten oikeuksien subjektista lopulta sosiaalisilla oikeuksilla varustetuksi vastuulliseksi yhteiskunnan jäseneksi.

Jos liberalistinen hallintorationaliteetti syntyi absoluuttisen valtion herruuden kritiikkinä, niin uusliberalistinen diskurssi on muodostunut hyvinvointivaltion kritiikkinä. Näin se on voinut hyödyntää myös sellaisten ryhmien hyvinvointivaltiokritiikkiä, jotka eivät välttämättä allekirjoittaisi uusliberalistista ohjelmaa (kuten kriittisen sosiologian, feminismin ja vapaan kansalaistoiminnan liikkeet). Keskeistä on hyvinvointivaltioon sisältyvän professionalismin kritiikki sekä väite hyvinvointivaltion tuottamasta riippuvuussuhteesta. Uusliberalistinen hallintorationaliteetti pyrkii riippumattomien kansalaisten tuottamiseen. Se nostaa yrittäjyyden korkeimpaan asemaan ja sen eettiset painotukset eivät liity niinkään suunniteltuun hyvään yhteiskuntaan vaan yrittäjyyteen liittyvään taloudelliseen lupaukseen. Yksilöistä on tultava oman itsensä yrittäjiä, ja tämä autonomisointi on sekä yksilöille että hallinnon yksiköille suunnattu eettinen ja taloudellinen ohje. Uusliberalismi haluaa yksityistää turvan käsitteen, joka jokaisen kansalaisen on hankittava itselleen yksityisten vakuutusten, terveyspalvelujen tai asuntotuotannon kautta. Näissä turvan hankinta voidaan liittää markkinakilpailun kurin takaamaan taloudelliseen tehokkuuteen.

Uusliberalismi ei hylkää valtiota kokonaan vaan jättää 
tälle tärkeän roolin kansakunnan etujen puolustajana ja sellaisen oikeusjärjestyksen ylläpitäjänä, joka mahdollistaa taloudellisten ja sosiaalisten suhteiden toimivuuden sekä yleisen turvallisuuden takaamisen. Samoin uusliberalismi ei ole esittänyt vain kaikkien hyvinvointijärjestelyjen poistamista vaan on tarjonnut uutta, tehokkaampaa sosiaalisen alueen hallinnointitapaa. Tässä hyvinvointijärjestelyn puutteet, kuten niukat voimavarat, käännetäänkin tulokselliseksi ihanteeksi. Niukkuus itsessään käännetään tehokkaammaksi toiminnaksi ja uudeksi elinvoimaksi. Hyvinvointivaltion "suvereenien" asiantuntijoiden valta on alistettava taloudelliselle järkiperäistämiselle ja kontrollille. Heistä on tehtävä palveluammattilaisia. Juuri itsenäisen budjetoinnin kautta asiantuntijat saadaan toisaalta yleiseen valvontaan sekä myös toimimaan yhä enemmän itsenäisinä taloudellisesti vastuullisina rationaalisina toimijoina. Lääkäreistä ja opettajista tehdään kustannushyötykalkyyliä jatkuvasti soveltavia toimijoita. Samoin yksilöiden elämänhallintaan on taattava eräänlainen jatkuva budjetointi sekä oman elämänsä hallinta. "Budjetoi tai näe nälkää" on uusliberalismin vastaus myös köyhyyden ongelmaan. Uusliberalismi ei suinkaan ole hylännyt vastuuntuntoisuuden ja yhteiskunnallisen järjestyksen teemaa. Ennemmin se uskoo, että kansalaisista on tullut vastuuntuntoisia ja että he kannattavat yhteiskunnalisia arvoja henkilökohtaisten pyrkimystensä ja onnellisuutensa takia eivätkä velvollisuudesta tai pakosta. Köyhyys ja muut kuvaan sopimattomat yhteiskunnalliset ongelmat voidaan hajottaa ihmisten luonteissa piileviksi vaikeuksiksi, joiden suhteen aineellisten voimavarojen puute näyttäytyy toissijaisena. Kodittomuus, alkoholismi, saamattomuus, huumeongelmat jne. määritellään marginaaliongelmiksi, jotka ovat kyllä yhteiskunnassa, mutta eivät synny yhteiskunnasta vaan kertovat maailmasta, jolta puuttuu vastuullisuuden ja itsensä kehittämisen hanke. Köyhiin on siten juurrutettava se eettinen ja kalkyloiva suhde omaan elämänsä, joka saisi heidät ehkäisemään köyhyyttään. Uuden rationalisuuden toiminta perustuu eettiseen ihanteeseen yritteliäästä, laskelmoivasta ja omaa etuaan maksimoivasta yksilöstä. Itse asiassa tässä suhteessa uusliberalismi on puhdasta oman elämän politiikkaa. Oman elämän hallinta pyritään juurruttamaan sisäistetyksi (taloudellisen kalkyylin) herruudeksi. Tässä suhteessa Foucault'n kysymys itsehallinnasta ja sen erilaisista historiallisista muodostumista osoittautuu jälleen hedelmälliseksi tavaksi analysoida moderneja hallinnon strategioita, joissa juuri subjektien itsehallinnan tekniikoiden osuus on keskeinen.

Foucault'n vaikutuksesta lukuisilla eri aloilla lupaa todistaa myös Clare O'Farralin toimittama valtava Foucault. The Legacy -teos, joka kokoaa Australiassa vuonna 1994 Surffaajien paratiisi -lomakeskuksessa nautintojen käyttöä opetelleiden tutkijoiden konferenssipapereita. Teoksen sisällysluettelo jakautuu epäilyttävän lukuisten teemojen alle: taide, arkkitehtuuri, filosofia, lääketiede, terveys, feminismi, psykoanalyysi, hallinto-oppi, kasvatus, ympäristö, julkissuhteet ja niin edelleen. Taiteen ja filosofian alta löytyy myös kaksi suomalaista akateemista lainelautailijaa: Mika Ojakankaan artikkeli "The Ethics of singularity in an Era of Complete Nihilism" ja Thomas Wallgrenin "Art, Politics and the History of Change". Kirja loppuu hieman kyynisen omituiseen O'Farrelin artikkeliin Foucault'n markkinoinnista! Tai ollaksemme reilumpia O'Farrelille, hänen kysymyksiään ovat: mikä on intellektuaalisen tiedon ja sen markkinoinnin suhde, tai mitä tapahtuu kun tekijästä tulee tuotemerkki? Tuotemerkissä tekijän käsitteen ongelmat nousevat uudelleen esiin. Onko kukaan kiinnostunut tuotemerkin sisällöstä vai riittävätkö pelkät "oikeat" nimilaput?

Mutta mikä oli tuotemerkki Foucault'n perintö, ei ainakaan yksi suuri oppi vaan kenties ainoastaan mahdollisuus äärettömälle diskurssille, loputtomille kysymyksille ilman institutionalisoitua alkua tai loppua. Kenties Samuel Beckettin sanoilla ilmaistu kehotus, jonka kautta Foucault mietti suhdettaan Jean Hippolyteen asettuessaan tämän paikalle College de Francessa:

"Sinun täytyy edetä, en voi edetä, tulen etenemään, sinun täytyy sanoa sanoja niin kauan kuin niitä on, kunnes ne löytävät minut, kunnes ne sanovat minut, outo kipu, outo synti, sinun täytyy edetä, kenties se on jo tehty, kenties minut on jo sanottu, kenties he ovat kantaneet minut tarinani kynnykselle, oven eteen, joka avautuu tarinaani, se yllättäisi minut, jos se aukenee."

Markku Koivusalo 


\section{$v$ i i t t e e t}

1. Ks. Foucault, Michel, "Qu'estce qu'un auteur". Teoksessa Foucault: Dits et Ecrits 1. Gallimard 1994.

2. Heidegger korosti äärellisyyden perustavaa ja positiivista roolia Kantin pyrkimyksessä asettaa ontologian perusta Puhtaan järjen kritiikissä. Samoin Heidegger pyrki irrottamaan äärellisyyden kysymyksen antropologiasta. "Alkuperäisempää kuin ihminen on äärellisyys hänessä [...], jos ihminen on ihminen ainoastaan Daseinin hänessä olemisen perustalta, silloin periaatteessa kysymys siitä, mikä on ihmistä alkuperäisempää, ei voi olla antropologinen. Kaikki antropologia, jopa filosofinen, on aina jo olettanut ihmisen olevan ihminen." Heidegger: Kant and the Problem of Metaphysics. Indiana University Press 1990, s. 156.

3. Michel Haar opettaa filosofiaa ja estetiikkaa Pariisin yliopisto XII:ssa ja on kirjoittanut fenomenologiasta sekä erityisesti Heideggerista ja Nietzschestä $\mathrm{mm}$. Heidegger et l'essence de l'homme. Millon 1990; Nietzsche et la métaphysique. Gallimard 1993. Dreyfus, joka on kirjoittanut Heideggerista, on toinen tekijä kenties eniten luetussa Foucault-kommentaarissa Michel Foucault: Beyond Structualism and Hermeneutics. Chigaco University Press 1980.

4. "Ainoastaan näin [tämän $a$ priorin paljastamisen kautta] voi olla a priori tiedettä, joka ylittää kaikki historialliset faktisiteetit. Ainoastaan tälle fundamentille perustuu tutkimuksen varmistettu kyky palata takaisin ajallisesti tyhjentyvistä itsestäänselvyyksistä alkuperäisiin itsestäänselvyyksiin.” Husserl, Edmund: Origin of geometry. Teoksessa The Crisis of European Sciences. Northwestern University Press 1970, s. 377.

5. Husserlille jokainen faktuaalinen historia joutuu olettamaan historiallisuuden a priori uni- versaaliuden: "Jokainen (pelkästään) faktoihin kiinnittyvä historia jää käsittämättömäksi, koska vetäessään johtopäätöksensä pelkästään naiivisti ja yksinkertaisesti faktoista, se ei koskaan tematisoi sitä yleistä merkityksen perustaa, jolla kaikki tällaiset johtopätökset lepäävät. Se ei ole koskaan tutkinut sille ominaista suunnatonta rakenteellista a prioria. Ainoastaan paljastamalla olemuksellisesti yleisen rakenteen, joka lepää nykyisyydessämme ja siten jokaisessa menneessä tai tulevassa historiallisessa nykyisyydessä sellaisenaan, ja totaalisuudessaan, ainoastaan paljastamalla konkreettisen, historiallisen ajan, jossa me elämme, jossa meidän koko ihmiskuntamme elää suhteessa sen totaaliseen ja olemukselliseen rakenteeseen - ainoastaan tämä paljastaminen voi mahdollistaa historiallisen tutkimuksen, joka on todella ymmärtävää, näkemyksellistä ja aidosti tieteellistä. Tämä on konkreettinen, historiallinen a priori, joka sisältää kaiken, mikä on olemassa historiallisena tulemisena ja tultuaan tai olleessaan olemassa olemuksellisesti traditiona ja perintönä." Husserl, emt., s. 371.

6. Foucault, Michel: The Archaeology of Knowledge. Tavistock 1972, s. 127.

7. "Mikään ei siten voisi olla herttaisempaa, tai epätarkempaa, kuin käsittää tämä historiallinen a priori formaaliksi $a$ prioriksi, joka on myös varustettu historialla: suuri, liikkumaton, tyhjä hahmo, joka eräänä päivänä tunkeutui ajan pinnalle ja harjoitti ihmisten ajattelun yli tyranniaa, jolta yksikään ei voinut paeta ja joka sitten yhtäkkiä katosi täysin odottomattomasti, täysin odottamattoman pimennyksen lailla: transsendentaalin rytmitys, jaksottaisten muotojen leikki." Foucault, emt., s. 128.

8. Foucault, Michel: "Les problèmes de la culture." Dits et écrits II. Gallimard, s. 373.

9. Vuoden 1975-76 luennot ovat ilmestyneet aikaisemmin myös
Italiaksi: Difendere la societá. Ponte alle Grazie, 1990.

10. Ks. Dumézil Georges: MitraVaruna. An Essay on two Indo-European Representations of Sovereignty. Zone Books 1988: "Toiseen (Varuna jne.) kuuluu se mikä on inspiroitunutta, ennakoimatonta, raivokasta, pikaista, maagista, kauheaa, pimeää, vaativaa, totalitaarista, inuior, jne.; kun taas toiseen (Mitra jne.) kuuluu se mikä on säännöllistettyä, eksaktia, majesteetillista, hidasta, oikeudellista, hyväntahtoista, valoisaa, liberaalia, jakavaa, senior jne." (S. 177.)

11. Pasquino, Pasquale: "Political theory of war and peace". Economy and Society 1/1993.

12. "Samat henkilöt voisivat siis olla sotilaita, maanviljelijöitä ja käsityöläisiä ja jopa neuvoston jäseniä ja tuomareita. [...] Saman on kuitenkin mahdotonta olla köyhä ja rikas. Siksi juuri rikkaat ja köyhät näyttävät olevan valtion tärkeimmät osat. Koska rikkaita on useimmiten vähän ja köyhiä paljon, valtion osista juuri nämä vaikuttavat vastakohtaisilta. Valtiomuodotkin on muodostettu jommankumman ylivallan mukaisiksi." Aristoteles: Politiikka IV, 1291b.

13. "Kaikissa kaupungeissa on näet kaksi puoluetta, jotka johtuvat siitä, että rahvas ei tahdo olla ylhäisön komennon ja sorron alaisena, ja ylhäiset taas puolestaan tahtovat vallita ja sortaa rahvasta." Machiavelli: Ruhtinas 1993, s. 60.

14. Rahvaasta Foucault'lla ks. myös Ojakangas: "Suvereeni ja Rahvas. Carl Schmitt kohtaa Michel Foucault'n". Teoksessa Politiikka pois paikoiltaan. Sakari Hännisen 50-vuotisjuhlakirja. Jyväskylän yliopiston valtioopin laitoksen julkaisuja, 1998.

15. Himmelfarb, G.: The Idea of Poverty: England in the Early Industrial Age. Alfred a Knopf 1984.

16. Dean, Mitchell: The Constitution of Powerty. London. 1991.

17. The Emergence of probability. Cambridge University Press 1975; The Taming of the 